\title{
Effect of different growth hormone (GH) mutants on the regulation of GH-receptor gene transcription in a human hepatoma cell line
}

\author{
Johnny Deladoëy, Grégoire Gex, Jean-Marc Vuissoz, Christian J Strasburger ${ }^{1}$, Michael P Wajnrajch ${ }^{2}$ and \\ Primus E Mullis \\ Department of Paediatrics, Division of Paediatric Endocrinology, Inselspital, CH-3010 Bern, Switzerland, ${ }^{1}$ Medizinische Klinik-Innenstadt, \\ Ludwig-Maximilians-Universität, Munich, Germany and ${ }^{2}$ Division of Paediatric Endocrinology, Weill Medical College of Cornell University, \\ New York, NY, USA \\ (Correspondence should be addressed to Primus E Mullis, University Children's Hospital, Inselspital, CH-3010 Bern, Switzerland; \\ Email: primus.mullis@insel.ch)
}

\begin{abstract}
Objective: $\mathrm{G}$ to A transition at position 6664 of the growth hormone (GH-1) gene results in the substitution of $\operatorname{Arg} 183$ by His (R183H) in the GH protein and causes a new form of autosomal dominant isolated GH deficiency (IGHD type II). The aim of this study was to assess the bioactivity of this $\mathrm{R} 183 \mathrm{H}$ mutant $\mathrm{GH}$ in comparison with both other $\mathrm{GH}$ variants and the $22-\mathrm{kDa} \mathrm{GH}$ in terms of GH-receptor gene regulation.

Design and Methods: The regulation of the GH-receptor gene (GH-receptor/GH binding protein, GHR/GHBP) transcription following the addition of variable concentrations $(0,12.5,25,50$ and $500 \mathrm{ng} / \mathrm{ml}$ ) of $\mathrm{R} 183 \mathrm{H}$ mutant $\mathrm{GH}$ was studied in a human hepatoma cell line (HuH7) cultured in a serum-free hormonally defined medium. In addition, identical experiments were performed using either recombinant human $\mathrm{GH}(22-\mathrm{kDa} \mathrm{GH})$ as a positive control or two $\mathrm{GH}$-receptor antagonists (R77C mutant GH and pegvisomant (B-2036-PEG)) as negative controls. GHR/GHBP mRNA expression was quantitatively assessed by RT-PCR amplification after $0,1,3$ and $6 \mathrm{~h}$ incubation.

Results: Following the addition of R183H mutant GH, GHR/GHBP mRNA changed at a similar rate to that seen in experiments where $22-\mathrm{kDa} \mathrm{GH}$ was added, indicating equal bioactivity. At all times and concentrations studied, the addition of R77C mutant $\mathrm{GH}$, however, resulted in a significantly lower increase $(P<0.001)$ of GHR/GHBP mRNA concentration compared with that caused by the addition of either 22-kDa GH or R183H mutant GH. Furthermore, in additional experiments, pegvisomant resulted in an absolute block of GHR/GHBP mRNA expression identical to that seen in control experiments where no 22-kDa GH was added at all.

Conclusions: These data indicate that the $\mathrm{R} 183 \mathrm{H}$ mutant $\mathrm{GH}$, although causing an autosomal dominant form of IGHD has an identical effect on GHR/GHBP transcription as its wild-type, the $22-\mathrm{kDa}$ GH. This implies that the IGHD caused by the R183H heterozygous mutation of the GH-1 gene is mainly due to a block of its regulated GH secretion. In addition, the R77C-GH variant and pegvisomant have an antagonistic effect at the level of GHR/GHBP transcription. All these data were confirmed by run-on experiments. In addition, these data highlight, as far as the GH variants are concerned, that a mutational alteration within the GH-1 gene might cause short stature also on the basis of an altered secretory pathway. This fact has to be taken into consideration when growth retardation is clinically diagnosed and studied at the molecular level. Secretory pathways and, therefore, cell-biological mechanisms are of importance and have to be considered in future not only at the scientific but also at the clinical level.
\end{abstract}

European Journal of Endocrinology 146 573-581

\section{Introduction}

The growth hormone-1 (GH-1) gene which encodes the $\mathrm{GH}$ protein is located on the long arm of chromosome 17 (17q22-24), and consists of five exons and four introns (1). This gene is mainly expressed in the pituitary gland and secreted as a protein, which is characterised by an antiparallel up-up down-down arrangement of four helices containing two disulphide bonds but no N-linked carbohydrate side chains (2). Approximately $75 \%$ of circulating human $\mathrm{GH}$ is expressed in the anterior pituitary as a major $22-\mathrm{kDa}$ 
product, whereas $5-10 \%$ of the remaining $\mathrm{GH}$ is a minor $(20-\mathrm{kDa})$ product, which is also bioactive at physiological concentrations (3).

Binding of $\mathrm{GH}$ to the $\mathrm{GH}$-receptor has been described as a sequential event (4). GH first associates with the GH-receptor to form a 1:1 complex through site 1 (the high affinity site) composed mainly of the long extended loop between helices 1 and 2 and the C-terminal part of helix 4. This complex is then capable of binding to a second receptor through site 2 of $\mathrm{GH}$, located mainly on helix 1 . Thereafter, following the ligand-mediated sterical alignment of the receptor dimer, signal transduction occurs.

Recently, we have reported four unrelated families whose members were suffering from a new form of autosomal dominant isolated $\mathrm{GH}$ deficiency (IGHD type II) (5). The dwarf phenotype co-segregated clearly with a G6664A transition mutation within exon five of the $G H-1$ gene. This mutation causes an arginine (R) to histidine $(\mathrm{H})$ amino acid (aa) change at position 183 in the $\mathrm{GH}$ protein $(\mathrm{R} 183 \mathrm{H})$ leading to a dominant negative expression of the GH-1 gene (5). All affected patients showed delayed growth and an impaired, but still present, $\mathrm{GH}$ release following standard pharmacological provocation tests (peak $\mathrm{GH}$ values $<10 \mathrm{mg} / \mathrm{l}$ ) $(5,6)$. Furthermore, we have shown that the GH deficiency in these autosomally affected patients presenting with this $\mathrm{R} 183 \mathrm{H} \mathrm{GH}-1$ gene mutation may be due to a marked blockade of the regulated GH secretion $(5,6)$. Of note is the fact that the Arg183 is highly conserved in the GH of different species $(7,8)$, and as the $\mathrm{R} 183 \mathrm{H}$ mutation takes place at the very end of helix 4 , it may have an impact on the binding affinity of site 1 towards the GH-receptor. In addition, there is a report by Cunningham and Wells (9) that the substitution of arginine by alanine at position 183 (R183A) caused a twofold weaker binding to the GH-receptor (site 1). Therefore, in order to shed light on the pathophysiology of this new autosomal dominant form of IGHD and to challenge our hypothesis that an altered regulatory secretion and not a biologically inactive form of $\mathrm{GH}$ is responsible for this disorder, the aim of the present study was to assess the biological activity of the $\mathrm{R} 183 \mathrm{H}$ mutant $\mathrm{GH}$ protein in comparison with the normal 22-kDa GH, as well as additional GH antagonists.

In this study, we used recombinant human GH (22-kDa GH; GH) as a positive control, whereas the R77C mutant GH $(10,11)$ and the GH receptorantagonist pegvisomant $(12,13)$ were used as negative controls.

Severe short stature in a boy due to a single mutation in the GH-1 gene was reported by Takahashi et al. (10). This missense mutation was predicted to convert codon 77 from arginine $(\mathrm{R})$ to cysteine $(\mathrm{C})$. The R77C mutant $\mathrm{GH}$ inhibited tyrosine phosphorylation in IM-9 cells 10 times more potently than the 22-kDa GH, showing an antagonistic or a dominant negative effect (10).
Pegvisomant (formerly known as Somavert, Trovert or B2036-PEG; Sensus Drug Development Corporation, Austin, TX, USA) is a 191 aa recombinant protein of DNA origin, identical to human $\mathrm{GH}$ except for eight mutations at binding site 1 and a single mutation within binding site 2 (glycine $(G)$ to arginine $(R)$ aa residue 120; G120R). These changes result in a substantially higher affinity of this molecule at binding site 1 while disrupting binding at site 2 and leaving the receptor inactive. In order to increase the antagonist's half-life and to reduce antibody formation, polyethylene glycol (PEG) is added (14).

The additional studies using these negative, antagonistically acting controls were of special interest because from the clinical point of view it might be important to know how effectively the GH receptor will be blocked by these antagonistic derivatives either normally occurring in patients or used as a new drug in acromegaly (13).

\section{Material and methods}

\section{Cell culture, mutant growth hormones and pegvisomant}

$\mathrm{HuH7}$ is a human hepatoma cell line that is reported to retain differentiated functions in culture (15), and therefore allows functional studies of GH-receptor gene expression. HuH7 cells were maintained in monolayer culture as previously described (16). When they had reached approximately $70 \%$ confluency, the medium was aspirated, the cells were washed twice with phosphate-buffered saline (PBS, pH 7.4; Sigma, St Louis, MO, USA) and $1 \mathrm{ml}$ of a serum-free hormonally defined medium was added. Briefly, serum-free hormonally defined medium contains $0.4 \mathrm{mmol} / \mathrm{l}$ ornithine; $2.25 \mu \mathrm{g} / \mathrm{ml}$ L-lactic acid; $2 \mathrm{ng} / \mathrm{ml}$ glucagon; $2.5 \times 10^{-8} \mathrm{~mol} / \mathrm{l}$ selenium; $5 \times 10^{-8} \mathrm{~mol} / \mathrm{l}$ hydrocortisone; $1 \times 10^{-6} \mathrm{~mol} / \mathrm{l}$ ethanolamine; $2 \mathrm{ng} / \mathrm{ml}$ choleratoxin; $1 \mu \mathrm{g} / \mathrm{ml}$ insulin, $1 \mu \mathrm{g} / \mathrm{ml}$ transferrin, $25 \mathrm{ng} / \mathrm{ml}$ epidermal growth factor (EGF) but, as previously reported, neither growth hormone nor insulin-like growth factor-I or -II (IGF-I, IGF-II) (17). After an overnight incubation, the medium was aspirated, the cells were washed twice with PBS ( $\mathrm{pH} 7.4)$ and the different samples containing variable forms of $\mathrm{GH}$ (22-kDa, R183H-GH, R77C-GH and pegvisomant) and variable concentrations $(12.5,25,50$ and $500 \mathrm{ng} / \mathrm{ml}$ of $\mathrm{GH}$ variants and, in the pegvisomant studies, an additional experiment using $20 \mu \mathrm{g} / \mathrm{ml}$ pegvisomant) were added to the culture medium for further incubation of either $0,1,3$ or $6 \mathrm{~h}$. In the clinical trial, due to pegvisomant's reduced affinity with the $\mathrm{GH}$ receptor as compared with the 22-kDa GH, the mean serum concentration of pegvisomant in the patients treated for acromegaly with a standard dose of $20 \mathrm{mg}$ per day was $20 \mu \mathrm{g} / \mathrm{ml}$ (13). Therefore, this additional dose was used in our in vitro experiments using pegvisomant. The incubation 
times were chosen based on previous experiments when marked differences of transcription rates of the GHR/GHBP (GH-receptor/GH binding protein) gene were seen at these times $(16,18)$. In addition, maximum internalisation of $\mathrm{GH}$ is reported after $2 \mathrm{~h}$, whereas hormone accumulation in the nucleus was saturated after $1 \mathrm{~h}$ (19). Each experiment was repeated four times.

R183H-GH was obtained from AtT-20 cells stably transfected with a vector containing R183H mutant GH cDNA producing R183H-GH (6). R77C mutant $\mathrm{GH}$ was expressed as a fusion protein with the E. coli thioridoxin gene $\operatorname{tr} x A$, extracted by sucrose treatment, and digested by enterokinase. Thereafter, the protein was purified using an anti-GH antibody-immobilised column and reverse-phase HPLC, confirmed by SDSPAGE, and assayed by ELISA using a GH-specific polyclonal antibody (11). The R183H mutant $\mathrm{GH}$ as well as the chromatographically purified R77C mutant GH were further diluted in serum-free hormonally defined medium to obtain the variable concentrations which were measured by an immunoradiometric assay (HGH Maia Clone, Biochem Immunosystems GmbH, Freiburg, Germany). It is important to stress that the affinities for the mutants and for the wild-type (wt)-form were tested and found to be equal. Interassay and intra-assay coefficients of variation were $2.7 \%$ and $1.8 \%$ respectively at $50 \mathrm{ng} / \mathrm{ml}$.

\section{RNA extraction}

RNA was extracted as previously described (16) using the acid guanidinium thiocyanate-phenol-chloroform method (20). The RNA concentration was measured by absorbance at $260 \mathrm{~nm}$ using a double beam Spectrophotometer (UV 150-02, Shimadzu Corporation, Tokyo, Japan).

\section{Construction of the internal control and synthesis of internal control RNA}

The plasmid for the preparation of synthetic internal control RNA (cRNA) was constructed by inserting a 50 base pair (bp) fragment of the rat prolactin (PRL) receptor DNA into a portion of the GHR cDNA as previously described (21). Briefly, the subsequent chimeric plasmid of GHR was cleaved with EcoRV and EcoRI, and a 545-bp fragment was obtained. This fragment was subcloned into the SmaI-EcoRI sites of bluescript SK+ (Stratagene Cloning System, San Diego, CA, USA). Following digestion with SalI, the chimeric GHR construct served as a template for in vivo transcription by T7 RNA polymerase to generate internal cRNA. The cRNA was purified with phenol-chloroform extraction and subsequently by oligo (deoxythymidine) chromatography. The absolute number of cRNA molecules was calculated using spectrophotometric absorbance at $260 \mathrm{~nm}$, the molecular weight of the cRNA molecule (216 600 g/mol) and Avogadro's number.

\section{Oliogonucleotide primers used for amplification}

Oliogonucleotide primers were purchased from Mycrosynth, Balgach, Switzerland. The sense primer was 5'-CCCTATATTGACAACATCAGTTCC-3', nucleotides 624-647 (exon 7; (22)) and the antisense primer was 5'-TTCCCTTCCTTGAGGAGATCTGG-3' ${ }^{\prime}$, nucleotides 931-954 (exon 9; (22)).

\section{cDNA synthesis and PCR amplification}

Four micrograms total RNA and $2.0 \times 10^{6}$ molecules internal control were reverse transcribed with $200 \mathrm{U}$ Moloney murine leukaemia virus reverse transcriptase (RT-M-MLV, Gibco-BRL, Life Technologies, Basel, Switzerland) primed with $1 \mu \mathrm{g}$ oligo (deoxythymidine) $12-18$ primer (Roche, Rotkreuz, Switzerland). The RT reaction was carried out in $20 \mu \mathrm{l}$ (total volume) RT-buffer $(50 \mathrm{mmol} / \mathrm{l} \mathrm{KCl}, 2 \mathrm{mmol} / \mathrm{l}$ $\mathrm{Mg}_{2} \mathrm{Cl}$, and $20 \mathrm{mmol} / \mathrm{l}$ Tris-HCl, $\left.\mathrm{pH} 8.3\right), 200 \mu \mathrm{mol} / \mathrm{l}$ deoxy-NTPs, $25 \mathrm{pmol}$ sense and antisense primers, $5 \mu \mathrm{l} 50 \%$ formamide, $1 \times 10^{6}$ c.p.m. ${ }^{32} \mathrm{P}$-end-labelled sense primer of the GH-receptor, and $1.5 \mathrm{U}$ AmpliTaq-DNA (Perkin-Elmer, Rotkreuz, Switzerland) in a total volume of $50 \mu \mathrm{l}$. Sense primer was 5 -end-labelled with $\left[\right.$ gamma- ${ }^{32} \mathrm{P}$ ]ATP $(>5000 \mathrm{Ci} / \mathrm{mmol}$; Amersham, Zürich, Switzerland) using T4 polynucleotide kinase (Amersham). The PCR amplification was carried out in 24 cycles as follows: $45 \mathrm{~s}$ denaturation at $94^{\circ} \mathrm{C}$, $1.5 \mathrm{~min}$ annealing at $55^{\circ} \mathrm{C}$, and $1.5 \mathrm{~min}$ extension at $72{ }^{\circ} \mathrm{C}$, after the initial denaturation at $95^{\circ} \mathrm{C}$ for $1.5 \mathrm{~min}$. Amplification was completed with an additional extension step at $72^{\circ} \mathrm{C}$ for $10 \mathrm{~min}$. PCR was performed in AMS (Protocol thermal cycler, AMS, Lugano, Switzerland).

\section{Analysis of the PCR-amplified cDNA product}

PCR products $(21 \mu \mathrm{l})$ were separated on 2\% Metaphor gel (FMC, Bioproduct, Bio Concept, Allschwill, Switzerland) and stained with ethidium bromide. The bands corresponding to each specific PCR product were excised from the gels, and the amount of incorporated radioactivity was determined in a $\beta$-scintillation counter (MR-300, automatic liquid scintillation system, Kontron, Zeiss AG, Zürich, Switzerland). Radioactivity (counts per min) was plotted against the amount of template (cRNA or target molecule). Gel pieces of the negative control were excised at the corresponding position and size as that of each positive band. The radioactivity of the negative control values served as background. 
Table 1 Number of GH-receptor mRNA molecules (GHR/GHBP mRNA) in HuH7 cells cultured in the presence of different forms of GH (22-kDa GH, R183H mutant GH, R77C mutant GH and GH-A pegvisomant) at various concentrations. By using quantitative PCR, the abundance of GHR/GHBP transcripts (expressed as molecules $\times 10^{6} / \mu \mathrm{g}$ total RNA) was measured at the beginning of the experiments $(0 \mathrm{~h})$ and after 1,3 and $6 \mathrm{~h}$.

\begin{tabular}{|c|c|c|c|c|c|c|c|}
\hline & \multicolumn{7}{|c|}{ GHR/GHBP mRNA $\left(\times 10^{6}\right.$ molecules/ $\mu \mathrm{g}$ total RNA $)$} \\
\hline & \multicolumn{7}{|c|}{ Incubation times } \\
\hline & $\mathrm{Oh}$ & $P$-value & $1 \mathrm{~h}$ & $P$-value & $3 \mathrm{~h}$ & $P$-value & $6 \mathrm{~h}$ \\
\hline \multicolumn{8}{|l|}{ 22-kDa GH } \\
\hline $0 \mathrm{ng} / \mathrm{ml}$ & $1.12 \pm 0.02$ & ns & $1.06 \pm 0.01$ & $<0.01$ & $0.89 \pm 0.02$ & $<0.01$ & $0.67 \pm 0.01$ \\
\hline $12.5 \mathrm{ng} / \mathrm{ml}$ & $1.09 \pm 0.02$ & ns & $1.13 \pm 0.02$ & ns & $1.08 \pm 0.02$ & ns & $1.07 \pm 0.01$ \\
\hline $25 \mathrm{ng} / \mathrm{ml}$ & $1.16 \pm 0.02$ & $<0.001$ & $1.32 \pm 0.02$ & $<0.01$ & $1.42 \pm 0.03$ & ns & $1.45 \pm 0.02$ \\
\hline $50 \mathrm{ng} / \mathrm{ml}$ & $1.17 \pm 0.02$ & $<0.001$ & $1.69 \pm 0.03$ & $<0.001$ & $2.09 \pm 0.04$ & $<0.001$ & $2.33 \pm 0.03$ \\
\hline $500 \mathrm{ng} / \mathrm{ml}$ & $1.20 \pm 0.02$ & $<0.001$ & $0.88 \pm 0.02$ & $<0.01$ & $0.62 \pm 0.01$ & $<0.001$ & $1.18 \pm 0.02$ \\
\hline \multicolumn{8}{|l|}{ R183H-GH } \\
\hline $12.5 \mathrm{ng} / \mathrm{ml}$ & $1.04 \pm 0.02$ & ns & $1.10 \pm 0.02$ & ns & $1.12 \pm 0.02$ & ns & $1.08 \pm 0.02$ \\
\hline $25 \mathrm{ng} / \mathrm{ml}$ & $1.08 \pm 0.01$ & $<0.001$ & $1.28 \pm 0.02$ & $<0.01$ & $1.36 \pm 0.03$ & ns & $1.42 \pm 0.03$ \\
\hline $50 \mathrm{ng} / \mathrm{ml}$ & $1.05 \pm 0.02$ & $<0.001$ & $1.58 \pm 0.02$ & $<0.001$ & $1.97 \pm 0.03$ & $<0.001$ & $2.28 \pm 0.03$ \\
\hline $500 \mathrm{ng} / \mathrm{ml}$ & $1.12 \pm 0.02$ & $<0.001$ & $0.76 \pm 0.02$ & $<0.01$ & $0.53 \pm 0.03$ & $<0.001$ & $1.07 \pm 0.02$ \\
\hline \multicolumn{8}{|l|}{ R77C-GH } \\
\hline $12.5 \mathrm{ng} / \mathrm{ml}$ & $1.04 \pm 0.02$ & ns & $1.05 \pm 0.02$ & ns & $1.02 \pm 0.01$ & ns & $1.03 \pm 0.01$ \\
\hline $25 \mathrm{ng} / \mathrm{ml}$ & $1.06 \pm 0.02$ & $<0.01$ & $1.19 \pm 0.02$ & $<0.01$ & $1.21 \pm 0.01$ & ns & $1.15 \pm 0.02$ \\
\hline $50 \mathrm{ng} / \mathrm{ml}$ & $1.03 \pm 0.02$ & $<0.01$ & $1.21 \pm 0.02$ & ns & $1.39 \pm 0.03$ & ns & $1.47 \pm 0.03$ \\
\hline $500 \mathrm{ng} / \mathrm{ml}$ & $1.09 \pm 0.02$ & $<0.01$ & $0.94 \pm 0.03$ & $<0.01$ & $0.87 \pm 0.02$ & ns & $0.95 \pm 0.03$ \\
\hline \multicolumn{8}{|c|}{ GH-A (pegvisomant) } \\
\hline $12.5 \mathrm{ng} / \mathrm{ml}$ & $1.03 \pm 0.01$ & ns & $0.95 \pm 0.03$ & $<0.01$ & $0.83 \pm 0.02$ & $<0.01$ & $0.69 \pm 0.03$ \\
\hline $25 \mathrm{ng} / \mathrm{ml}$ & $1.08 \pm 0.02$ & ns & $0.97 \pm 0.02$ & $<0.01$ & $0.79 \pm 0.03$ & ns & $0.72 \pm 0.02$ \\
\hline $50 \mathrm{ng} / \mathrm{ml}$ & $1.03 \pm 0.02$ & $<0.01$ & $0.91 \pm 0.02$ & ns & $0.86 \pm 0.02$ & $<0.001$ & $0.69 \pm 0.02$ \\
\hline $500 \mathrm{ng} / \mathrm{ml}$ & $1.01 \pm 0.02$ & ns & $0.98 \pm 0.02$ & ns & $0.87 \pm 0.01$ & $<0.001$ & $0.65 \pm 0.02$ \\
\hline $20 \mu \mathrm{g} / \mathrm{ml}$ & $1.04 \pm 0.01$ & ns & $0.98 \pm 0.02$ & ns & $0.91 \pm 0.01$ & ns & $0.82 \pm 0.01$ \\
\hline
\end{tabular}

ns, not significant.

\section{Quantification of growth hormone-receptor mRNA}

The radioactivity recovered from each gel slice was plotted against either the amount of total RNA (nanograms) or cRNA (molecules). Previous studies have shown that the two curves are parallel and exponential for both cRNA and GHR/GHBP mRNA, suggesting that the quantitative PCR is equally efficient for both controls and target RNA without any competition that could interfere with reliable quantification (21).

\section{Nuclear run-on transcription}

Nuclear run-on assays were performed as previously described $(16,18)$. Briefly, nuclei were isolated from freshly washed pellets of GH-treated or untreated human hepatoma cells (HuH7) and initiated transcripts were allowed to extend in the presence of $\left[\alpha-{ }^{32} \mathrm{P}\right] \mathrm{CTP}$ $(3000 \mathrm{Ci} / \mathrm{mmol}$, New England Nuclear, Perkin Elmer Life Sciences, Freiburg, Germany). Each run-on probe was hybridised with one of four identical filters dotblotted with $10 \mu \mathrm{g}$ of each GHR clone, $\beta$-tubulin clone pD $\beta-1 S K 1$ DNA and plasmid Bluescript SK+ DNA, as a negative control. After cross-linking of the DNA to the filters (Hybond-C, Amersham), the filters were pre-hybridised overnight at $42{ }^{\circ} \mathrm{C}$. Run-on probe $(6 \times 107$ c.p.m.) synthesised from treated or untreated HuH7 cell nuclei was added, and the filters hybridised at $42{ }^{\circ} \mathrm{C}$ for $72 \mathrm{~h}$. The filters were washed, dried and autoradiographed. The strength of each autoradiographic signal was determined by liquid scintillation spectroscopy of excised filter pieces $(16,18)$. Briefly, the ratio of the counts corresponding to the GHR mRNA/ $\beta$-tubulin mRNA at time $3 \mathrm{~h}$ without any $\mathrm{GH}$ added was arbitrarily set as 1.0 unit, and other data were expressed as GHR/GHBP run-on transcription units using this base-line. Importantly, $\beta$-tubulin mRNA levels in $\mathrm{HuH7}$ cells did not change as a result of GH treatment and could, therefore, be used to control for small variations in the quantity of RNA present in each sample analysed. The values obtained

Figure 1 Quantitative RT-PCR amplification: time course of effects of different concentrations of 22-kDa GH (a-c), as well as of different mutant GH forms ((a) R183H-GH; (b) R77C-GH; (c) pegvisomant) on GHR/GHBP gene expression (GHR/GHBP mRNA) in a human hepatoma cell line (HuH7). The cells were cultured in serum-free hormonally defined medium, and were harvested for RNA extraction at $0,1,3$ and $6 \mathrm{~h}$ after the addition of either $22-\mathrm{kDa} \mathrm{GH}$ or the variable forms of GH mutants. Values plotted are means of values obtained from four individual cultures (see Table 1). 

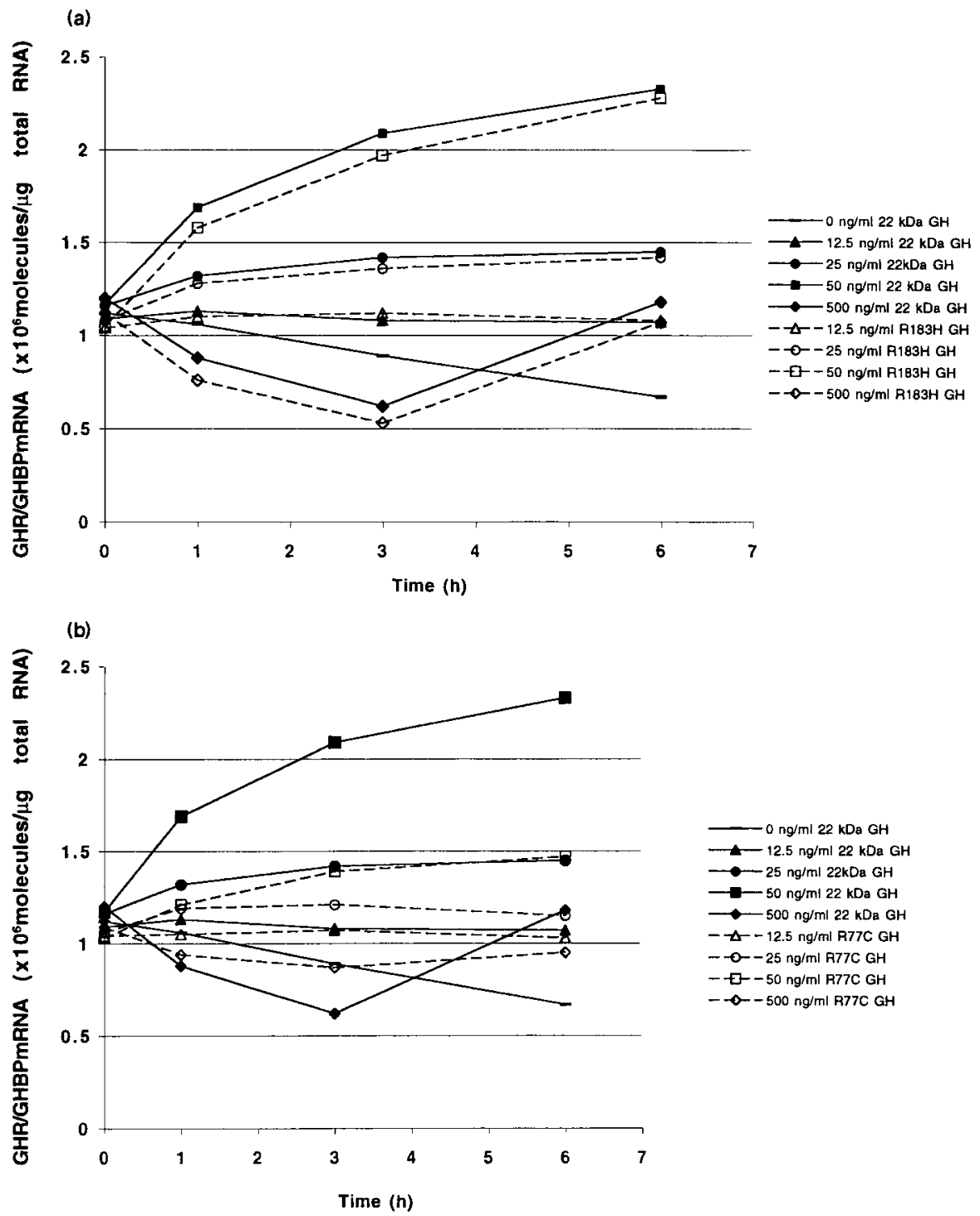

(c)
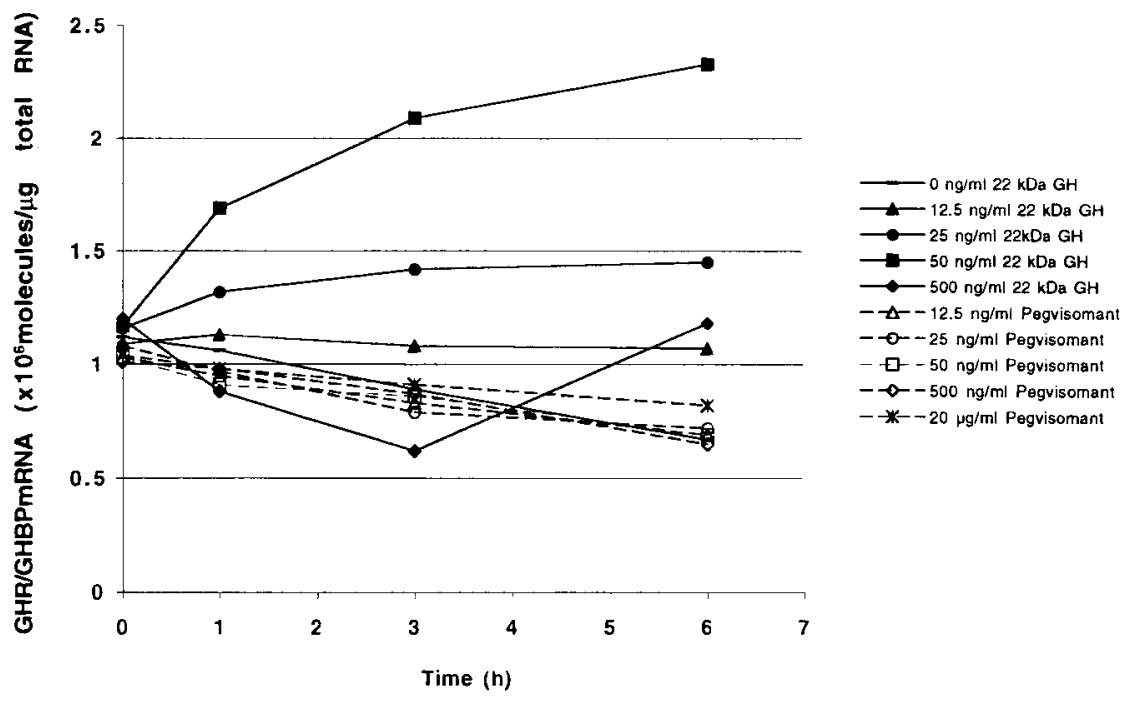
were checked against values obtained by scanning densitometry (Bio-Rad Model 620 Video Densitometer, Bio-Rad Laboratories, Hemel Hempstead, Herts, UK) of the autoradiograph, and were found to correlate significantly (r: $0.85 ; P<0.001)$. In order to analyse whether the changes in the rate of GHR/GHBP gene transcription were dependent upon protein synthesis, a second set of experiments was performed where cycloheximide was added to the culture medium at a concentration of $10 \mu \mathrm{g} / \mathrm{ml}, 30 \mathrm{~min}$ before either $\mathrm{GH}$ and/or GH mutants.

\section{Statistical analysis}

Statistical differences among experimental groups were determined by Student's unpaired two-tailed $t$-test or ANOVA followed by post-hoc test by Newman-Keuls where appropriate. Values of $P<0.05$ were considered significant. Values are expressed as means ( \pm s.e.M.) unless otherwise stated.

\section{Results}

HuH7 cells were cultured in the presence of different forms of $\mathrm{GH}$ (22-kDa GH, R183H mutant GH, R77C mutant $\mathrm{GH}$ and pegvisomant) at variable concentrations. By using quantitative PCR, the abundance of GHR/GHBP transcripts was measured at the beginning of the experiments as well as after 1,3 and $6 \mathrm{~h}$. The overall data of the $\mathrm{GH}$ experiments performed are summarised in Table 1 and Fig. 1a-c.

\section{After addition of recombinant human growth hormone (22-kDa GH, GH)}

A dose-dependent effect on GHR/GHBP gene expression was seen when physiological doses of 12.5 and $25 \mathrm{ng} / \mathrm{ml} \mathrm{GH}$ were added to the culture medium (Table 1 and Fig. 1a). Importantly, treatment with a concentration of $50 \mathrm{ng} / \mathrm{ml} \mathrm{GH}$ resulted in a most significant increase of GH-receptor (GHR/GHBP) mRNA molecules expressed as the number of molecules $\times 10^{6} / \mu \mathrm{g}$ total RNA. The increase was already obvious $1 \mathrm{~h}$ after addition of GH. However, when a supraphysiological concentration of $500 \mathrm{ng} / \mathrm{ml} \mathrm{GH}$ was given to the HuH7 cells, a decrease of GHR/GHBP mRNA expression was observed in the first $3 \mathrm{~h}$ of the assay before it returned to a level of expression close to that present at the beginning of the experiment (Fig. 1 and Table 1). These results were similar to previous studies performed under identical conditions $(16,18)$.

\section{After addition of R183H mutant GH}

Overall, using variable R183H-GH concentrations a parallel and roughly equal dose-response effect on the GHR/GHBP gene expression to that seen with the 22-kDa GH was found ( $P=$ not significant; Table 1 and Fig. 1a).

\section{After addition of R77C mutant GH}

Although the overall increase of GHR/GHBP mRNA expression was significant in the $\mathrm{R} 77 \mathrm{C}$ mutant $\mathrm{GH}$ experiments when compared with the data obtained in the experiments with no $\mathrm{GH}$ added $(1 \mathrm{~h}, P<0.01$; $3 \mathrm{~h}, P<0.001 ; 6 \mathrm{~h}, P<0.001)$, R77C mutant $\mathrm{GH}$ showed a significantly lower effect on GHR/GHBP expression than the 22-kDa GH (Table 1, Fig. 1b). The doses of 12.5 and $25 \mathrm{ng} / \mathrm{ml}$ presented a significantly lower increase of GHR/GHBP expression compared with the effect obtained using 22-kDa GH (at incubation time $3 \mathrm{~h}$ using $12.5 \mathrm{ng} / \mathrm{ml}, \quad P<0.01$; $25 \mathrm{ng} / \mathrm{ml}, P<0.001$; at incubation time $6 \mathrm{~h}$ using $12.5 \mathrm{ng} / \mathrm{ml}, P<0.01 ; 25 \mathrm{ng} / \mathrm{ml}, P<0.001)$. Moreover, after 1 -h incubation with $50 \mathrm{ng} / \mathrm{ml}$ R77C mutant GH, a significant increase of the GHR/GHBP mRNA level became obvious $(P<0.01)$ and, thereafter, the GHR/GHBP mRNA levels remained largely unchanged until the end of the experiments. Furthermore, when compared with the data obtained using 22-kDa GH the differences were significant: at incu-

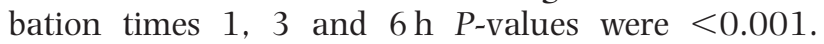
When $500 \mathrm{ng} / \mathrm{ml} \mathrm{GH}$ were added to the culture medium, the down-regulation on GHR/GHBP transcription was significantly less (at incubation time $1 \mathrm{~h}, \mathrm{P}<0.01$; at 3 and $6 \mathrm{~h}, P<0.001)$.

\section{After addition of the GHR-antagonist pegvisomant}

The addition of any dose of pegvisomant $(12.5 \mathrm{ng} / \mathrm{ml}$, $25 \mathrm{ng} / \mathrm{ml}, 50 \mathrm{ng} / \mathrm{ml}, 500 \mathrm{ng} / \mathrm{ml}$ as well as $20 \mu \mathrm{g} / \mathrm{ml}$ ) had no effect on GHR/GHBP expression (Table 1 and Fig. 1c). The different levels reached were more or less similar to the data obtained in the experiments where no GH was added and, therefore, at any time and concentration they were highly significantly different $(P<0.001)$ when compared with the expression levels obtained in the experiments where 22-kDa GH was used.

\section{Run-on assay}

By performing nuclear run-on experiments we also examined the question of whether the changes in GHR/GHBP gene transcription levels were real, and were therefore a result of a changed rate of transcription. HuH7 cells were cultured for $3 \mathrm{~h}$ in the presence of different concentrations (50 and $500 \mathrm{ng} / \mathrm{ml}$; and $20 \mu \mathrm{g} / \mathrm{ml}$ in the case of pegvisomant) and forms of GH (22-kDa GH; R183H-GH; R77C-GH; pegvisomant) and/or under the same condition as the cells used for RNA quantification. The doses of 50 and $500 \mathrm{ng} / \mathrm{ml}$ 
were chosen because they were expected to result in the most significant differences in transcription rates. Nuclei were prepared from freshly isolated cells and radiolabelled run-on probes were synthesised and hybridised to filters carrying GHR/GHBP and $\beta$-tubulin cDNA fragments. The results are shown in Fig. 2. Importantly, the data were consistent with the results obtained in the quantitative RT-PCR experiments. In order to analyse whether the changes in the rate of GHR/GHBP gene transcription depended on protein synthesis, cycloheximide $(10 \mu \mathrm{g} / \mathrm{ml})$ was added to the culture medium $30 \mathrm{~min}$ before the GH. The levels of the run-on transcripts remained unchanged in all the experiments (Fig. 2). This indicates that the regulating effects of $\mathrm{GH}$ on the GHR/GHBP gene transcription were dependent, at least partly, on pre-existing factors and did not require protein synthesis.

\section{Discussion}

Autosomal dominant familial isolated $\mathrm{GH}$ deficiency (IGHD type II) is a rare cause of human IGHD in which the majority of mutations described so far have occurred around the exon 3/IVS3 region (del32-71 mutant GH) of the GH-1 gene $(5,23-25)$. In these individuals, even though one normal $G H-1$ allele is present, the secreted human GH levels are severely decreased (25). Furthermore, when both normal and del32-71mutant $\mathrm{GH}$ were co-expressed in different cell lines, the dominant negative expression of the GH-1 gene was observed in neuroendocrine cell lines (26) in which the del32-71 mutant GH caused GH deficiency by decreasing the intracellular stability of the normal GH (27). Therefore, whereas the autosomal dominant form of GH-deficiency in the heterozygous patients presenting the del32-71 GH mutation may be caused by a decreased intracellular GH stability and/or increased cytosolic degradation, the pathophysiological mechanism in our recently reported patients with the heterozygous $\mathrm{R} 183 \mathrm{H}$ mutant $\mathrm{GH}$ is suggested to be different. The effect of the R183H mutation in the GH-1 gene is likely due to an intracellular trafficking or packaging defect. Thus, we aimed to test this mutant $\mathrm{GH}$ for its bioactivity in terms of GHR/GHBP gene transcription and to analyse the impact of different $\mathrm{GH}$ forms on the GHR/GHBP gene transcription in a human hepatoma cell line (HuH7 cells). First, in order to obtain base-line data, experiments using variable 22-kDa GH concentrations, as previously reported,

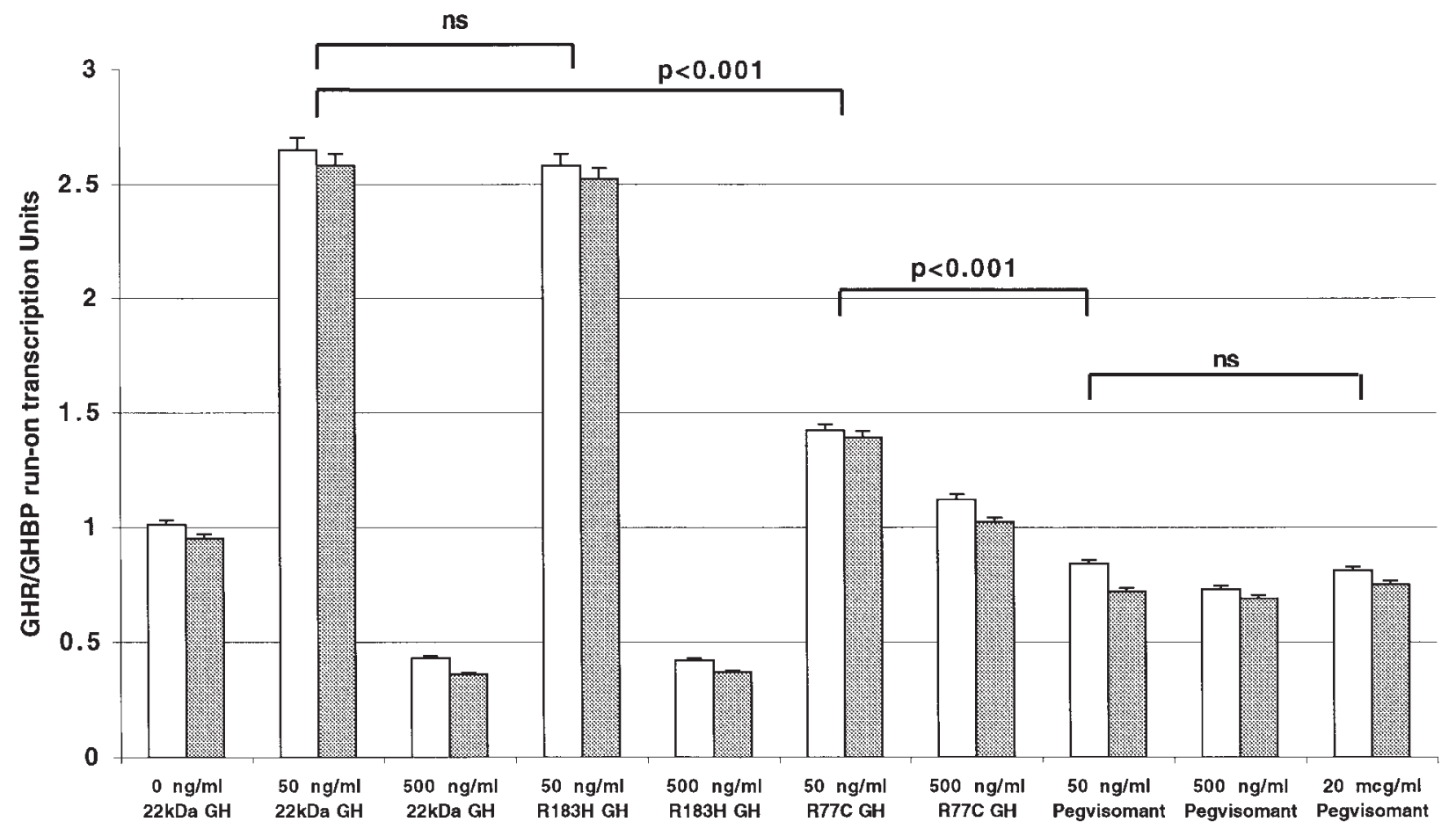

Figure 2 Run-on experiments: effects of different concentrations (50 and $500 \mathrm{ng} / \mathrm{ml}$; in addition $20 \mu \mathrm{g} / \mathrm{ml}$ pegvisomant) of $22-\mathrm{kDa} \mathrm{GH}$ or variable forms of mutant $\mathrm{GH}$ (R183H-GH; R77C-GH; pegvisomant) following a 3-h incubation on transcription of $G H R / G H B P$ gene in human hepatoma cells (HuH7). The autoradiographic signals were quantified by liquid scintillation counting of filter pieces as described in Methods. The ratio obtained with GHR/GHBP target DNA to that obtained with the $\beta$-tubulin target DNA was calculated for each set of culture conditions. This ratio was arbitrarily set at $1 \mathrm{U}$ for untreated $\mathrm{HuH} 7$ cells, and other values were adjusted accordingly and plotted. Values shown are means of values obtained in four parallel experiments from four individual cultures. The lines above the bar indicate S.E.M.; open bars, without cycloheximide; hatched bars, with cycloheximide. 
were repeated and these data were confirmed (Table 1 and Fig. 1) (16, 18). Moreover, importantly, 22-kDa $\mathrm{GH}$ and R183H-GH have been found to have almost identical bioactivity in the regulation of $G H R / G H B P$ gene transcription (Table 1, Fig. 1).

In addition, Takahashi et al. (10) reported a child whose short stature was caused by a single mutant GH-1 gene allele (missense mutation: at codon 77, arginine to cysteine; R77C). The R77C mutant $\mathrm{GH}$ possessed not only a 6 times greater affinity to the GHBP but also inhibited the tyrosine phosphorylation in the IM-9 cells 10 times more potently than the $22-\mathrm{kDa}$ GH $(10,28)$ showing an antagonistic or a dominant negative action. Therefore, in our experiments we aimed to follow the effect on GHR/GHBP gene transcription of this antagonistic $\mathrm{GH}$ mutant. Interestingly, we were able to confirm the antagonistic effect of the $\mathrm{R} 77 \mathrm{C}$ mutant $\mathrm{GH}$ variant also at the level of GH-receptor expression. This fact is of importance because GH-receptor transcription rate might correlate at least partially with bioactivity.

In the last part of our study the genetically engineered analogue of human GH, pegvisomant, (Somavert, Trovert or B2036-PEG) which functions as a GHR antagonist, was examined in terms of its blocking effect of GHR/GHBP expression. Because in the clinical trial looking at the efficacy and tolerability of pegvisomant in patients suffering from acromegaly, the mean serum concentration of pegvisomant given at a daily dose of $20 \mathrm{mg}$ was found to be about $20 \mu \mathrm{g} / \mathrm{ml}$, similar doses were additionally used in our in vitro experiments (13). The findings were most impressive: pegvisomant was able to inhibit any GHR/GHBP gene transcription at any concentration used.

Most importantly, however, all these data focusing on GHR/GHBP gene transcription derived from cDNA synthesis and quantitative PCR amplification using an internal control for standard purposes were confirmed by run-on experiments (Fig. 2). In addition, cycloheximide did not affect these changes, supporting the notion that the $G H R / G H B P$ gene transcription is directly stimulated.

In conclusion, we present data showing that the different $\mathrm{GH}$ mutants have a specific and direct impact on GH/GHBP gene transcription. R183H mutant $\mathrm{GH}$ has the same bioactivity as the normal 22-kDa GH, whereas the R77C mutant GH has a slight antagonistic effect on the GHR/GHBP at its transcriptional level. Finally, pegvisomant is a potent GHR antagonist. These data indicate that R183H, although causing an autosomal dominant form of IGHD, has an identical effect on GHR/GHBP transcription as the wild-type, 22-kDa GH. This implies that the IGHD caused by the $\mathrm{R} 183 \mathrm{H}$ heterozygous mutation of the GH-1 gene is mainly due to a block of the regulated $\mathrm{GH}$ secretion. In addition, the $\mathrm{R} 77 \mathrm{C}-\mathrm{GH}$ variant as well as pegvisomant have an antagonistic effect at the level of GHR/GHBP transcription. All these data were confirmed by run-on experiments. In addition, these data highlight, as far as the GH variants are concerned, that a mutational alteration within the $\mathrm{GH}-1$ gene might cause short stature also on the basis of an altered secretory pathway. This fact has to be taken into consideration when growth retardation is clinically diagnosed and studied at the molecular level. Secretory pathways and therefore cell-biological mechanisms are of importance and have to be considered in future not only at the scientific but also at the clinical level.

\section{Acknowledgements}

We thank Dr Liz Bürgi for her help and valuable advice while reviewing the manuscript, and Andrée Eblé for technical assistance. In addition, we would like to acknowledge Yutaka Takahashi, Third Division, Department of Medicine, Kobe University School of Medicine, Kobe, Japan, for providing the recombinant R77C mutant GH. Furthermore, pegvisomant was kindly provided by Drs J C Scarlett, W F Bennett and R Davis of Sensus Corp., Austin, TX, USA. The study was supported by The Swiss National Science Foundation (3200-53724.98) (to P E M) and by a $\mathrm{MD}-\mathrm{PhD}$ grant from the Swiss Academy of Medical Sciences (to J D).

\section{References}

1 Chen EY, Liao YC, Smith DH, Barerra-Saldana HA, Gelinas RE \& Seeburg PH. The human growth hormone locus: nucleotide sequence, biology, and evolution. Genomics $19894479-487$.

2 De Vos AM, Ultsch M \& Kossiakoff AA. Human growth hormone and extracellular domain of its receptor: crystal structure of the complex. Science 1992255 306-312.

3 Nuoffer JM, Flück C, Deladoëy J, Eblé A, Dattani MT \& Mullis PE. Regulation of human growth hormone $(\mathrm{GH})$ receptor gene transcription by 20- and 22-kilodalton $\mathrm{GH}$ in a human hepatoma cell line. Journal of Endocrinology 2000165 313-320.

4 Cunningham BC, Ultsch M, de Vos AM, Mulkerrin MG, Clauser KR \& Wells JA. Dimerization of the extracellular domain of the human growth hormone receptor by a single hormone molecule. Science $1991 \mathbf{2 5 4 8 2 1 - 8 2 5 .}$

5 Wajnrajch MP, Gertner JM, Mullis PE, Deladoëy J, Cogan JD, Lekhakula S et al. Arg183His, a new mutational hot-spot in the growth hormone $(\mathrm{GH})$ gene causing isolated $\mathrm{GH}$ deficiency type II. Journal of Endocrine Genetics 20001 125-135.

6 Deladoëy J \& Mullis PE. Effect of the dominant negative human growth hormone (hGH) gene mutation Arg183His on the regulated secretory pathway. Growth Hormone and IGF Research 200010148.

7 Nicoll CS, Mayer GL \& Russel SM. Structural features of prolactins and growth hormones that can be related to their biological properties. Endocrine Review 19867 169-203.

8 Hulmes J, Miedel MC, Li HL \& Pan YCE. Primary structure of elephant growth hormone. International Journal of Peptide and Protein Research 198933 368-372.

9 Cunningham BC \& Wells JA. High-resolution epitope mapping of hGH-receptor interactions by alanine-scanning mutagenesis. Science $19892441081-1085$. 
10 Takahashi Y, Hidesuke K, Okimura Y, Goji K, Abe H \& Chihara K. Brief report: short stature caused by a mutant growth hormone. New England Journal of Medicine $1996334432-436$.

11 Takahashi Y, Shirono H, Arisaka O, Takahashi K, Yagi T, Koga J et al. Biological inactive growth hormone caused by an amino acid substitution. Journal of Clinical Investigation $1997 \mathbf{1 0 0}$ 1159-1165.

12 Thorner MO, Strasburger CJ, Wu Z, Straume M, Bidlingmaier M, Pezzoli SS et al. Growth hormone $(\mathrm{GH})$ receptor blockade with a PEG-modified GH (B2036-PEG) lowers serum insulinlike growth factor-I but does not acutely stimulate serum $\mathrm{GH}$. Journal of Clinical Endocrinology and Metabolism $1999 \mathbf{8 4}$ 2098-2103.

13 Trainer PJ, Drake WM, Katznelson L, Freda PU, Herman-Bonert V, Van Der Lely AJ et al. Treatment of acromegaly with the growth hormone-receptor antagonist pegvisomant. New England Journal of Medicine $20003 \mathbf{3 4 2} 1171-1177$.

14 Parkinson C \& Trainer PJ. Growth hormone receptor antagonists therapy for acromegaly. Baillières Best Practice and Research, Clinical Endocrinology and Metabolism 199913 419-430.

15 Nakabayashi N, Taketa K, Miyano K, Yamane T \& Sato K. Growth of human hepatoma cell lines with differentiated functions in chemically defined medium. Cancer Research $1982 \mathbf{4 2}$ 3858-3863.

16 Mullis PE, Lund T, Patel MS, Brook CGD \& Brickell PM. Regulation of human growth hormone receptor gene expression by human growth hormone in a human hepatoma cell line. Molecular and Cellular Endocrinology 199176 125-133.

17 Barash I, Cromlish W \& Posner BI. Prolactin (PRL) receptor induction in cultured rat hepatocytes: dual regulation by PRL and growth hormone. Endocrinology $19881221151-1158$.

18 Mullis PE, Holl RW, Lund T, Eblé A \& Brickell PM. Regulation of human growth hormone-binding protein production by human growth hormone in a hepatoma cell line. Molecular and Cellular Endocrinology $1995 \mathbf{1 1 1} 181-190$.

19 Lobie PE, Mertani H, Norel G, Morales-Bustos O, Norstedt G \& Waters MJ. Receptor mediated nuclear translocation of growth hormone. Journal of Biological Chemistry 1994269 21330-21339.

20 Chomczynski P \& Sacchi N. Single-step method of RNA isolation by guanidinium thiocyanate-phenol-chloroform extraction. Analytical Biochemistry $1987 \mathbf{1 6 2} 156-159$.
21 Martini JF, Villares SM, Nagano M, Delehaye-Zervas MC, Eymard B, Kelly PA et al. Quantitative analysis by polymerase chain reaction of growth hormone receptor gene expression in human liver and muscle. Endocrinology $1995 \mathbf{1 3 6}$ 1355-1360.

22 Leung DW, Spencer SA, Cachiaces G, Hammonds RG, Collins C, Henzel WJ et al. Growth hormone receptor and serum binding protein: purification, cloning and expression. Nature $1987 \mathbf{3 3 0}$ 537-543.

23 Cogan JD, Phillips JA, Schenkmann SS, Milner RDG \& Sakati N. Familial growth hormone deficiency: a model of dominant and recessive mutations affecting a monomeric protein. Journal of Clinical Endocrinology and Metabolism 199479 1261-1265.

24 Cogan JD, Ramel B, Lehto M, Phillips JA 3rd, Prince M, Blizzard $\mathrm{RM}$ et al. A recurring dominant negative mutation causes autosomal dominant growth hormone deficiency - a clinical research center study. Journal of Clinical Endocrinology and Metabolism 1995 803591 - 3595.

25 Binder G \& Ranke MB. Screening for growth hormone (GH) gene splice-site mutations in sporadic cases with severe isolated $\mathrm{GH}$ deficiency using ectopic transcript analysis. Journal of Clinical Endocrinology and Metabolism 199580 1247-1252.

26 Hayashi Y, Yamamoto M, Ohmori S, Kamijo T, Ogawa M \& Seo H. Inhibition of growth hormone $(\mathrm{GH})$ secretion by a mutant $\mathrm{GH}-1$ gene product in neuroendocrine cells containing secretory granules: an implication for isolated GH deficiency inherited in an autosomal dominant manner. Journal of Clinical Endocrinology and Metabolism $1999 \mathbf{8 4} 2134-2139$.

27 Lee MS, Wajnrajch MP, Kim SS, Plotnick LP, Wang J, Gertner JM et al. Autosomal dominant growth hormone (GH) deficiency type II: the del32-71-GH deletion mutant suppresses secretion of wild-type GH. Endocrinology $2000141883-890$.

28 Chihara K, Takahashi Y, Kaji H, Goji K, Okimura Y \& Abe H. Short stature caused by a natural growth hormone antagonist. Hormone Research 199849 (Suppl 1) 41-45.

Received 27 July 2001

Accepted 31 October 2001 